\title{
Comparison of omeprazole with ranitidine for treatment of symptoms associated with gastroesophageal reflux disease and uncomplicated duodenal ulcer
}

\begin{abstract}
ANDRE P ARCHAMBAULT MD FRCPC, RICHARD H HUNT MB FRCPC, IGM ClEATOR MB FRCPC, LLOYD R SUTHERLAND MD FRCPC, Alan BR THOMSON MD FRCPC, C NOEL Williams MB FRCPC, D WAYNE TAYLOR BSc, ANN M DRYSDALE RN BScN
\end{abstract}

\begin{abstract}
AP ARChAmbault, RH Hunt, IGM CleAtor, et al. Comparison of omeprazole with ranitidine for treatment of symptoms associated with gastroesophageal reflux disease and uncomplicated duodenal ulcer. Can J Gastroenterol 1996: 10(3):156-162. This randomized, single-blind, parallel group study was conducted to compare omeprazole with ranitidine for the treatment of symptoms associated with gastroesophageal reflux disease (GERD), uncomplicated duodenal ulcer (DU) or both. After baseline assessments, patients were randomized to receive daily treatment with either $20 \mathrm{mg}$ omeprazole or $300 \mathrm{mg}$ ranitidine for four weeks. In total, 1481 patients (1001 omeprazole, 480 ranitidine) with a diagnosis of GERD $(n=904)$ and/or DU $(n=577)$, confirmed by endoscopy or barium meal and reporting moderate to severe symptoms, were included in the analyses. The seventy of overall daytime symptoms reported by the omeprazole group at clinic visits was lower than that reported by the ranitidine group at week 2 for the entire patient group $(\mathrm{P}=0.0002)$ and at both weeks 2 and 4 for the subgroup of patients with GERD $(\mathrm{P}=0.0001$ and $\mathrm{P}=0.001$, respectively). The severity of overall night-time symptoms reported by the omeprazole group was lower than that reported by the ranitidine group at week 4 for all patients as a whole $(\mathrm{P}=0.042)$ and at both weeks 2 and 4 for the subgroup of patients with GERD $(\mathrm{P}=0.035$ and $\mathrm{P}=0.010$, respectively). There were no significant differences in reports of adverse events. In the omeprazole group,
\end{abstract}

$19 \%$ of patients at week 2 and $15 \%$ of patients at week 4 reported adverse events, while the corresponding results from the ranitidine group were $21 \%$ and $11 \%$. In conclusion, patients with GERD, DU or both treated with omeprazole $20 \mathrm{mg}$ daily for four weeks showed statistically significant reductions in symptoms compared with patients treated with ranitidine $300 \mathrm{mg}$ daily for the same period of time. The percentage of patients with any remaining daytime symptoms was $12 \%$ lower in the omeprazole group compared with the ranitidine group at week 2 , and $7 \%$ lower at week 4 . Five per cent fewer patients in the omeprazole group experienced night-time symptoms at either week 2 or week 4 .

Key Words: Duodenal ulcer, Gastroesophageal reflux, Omeprazole, Pain, Ranitidine, Symptom

Comparaison de l'oméprazole et de la ranitidine dans le traitement des symptômes associés à l'oesophagite de reflux et à l'ulcère duodénal non compliqué

RÉSUMÉ : Cette étude randomisée à simple insu avec groupe parallèle a été menée afin de comparer l'oméprazole et la ranitidine dans le traitement des symptômes associés à l'oesophagite de reflux et à l'ulcère duodénal non compliqué ou aux deux. Après une évaluation de départ, les patients ont été assignés de façon aléatoire afin de re-

voir page suivante

St Paul's Hospital, Vancouver, British Columbia; Foothills Hospital, Calgary, Alberta; Division of Gastroenterology, University of Alberta,

Edmonton, Alberta; McMaster University, Hamilton, Ontario; Hôpital Maisonnevue-Rosemount, Montreal, Quebec; Division of

Gastroenterology, Department of Medicine, Dalhousie University, Halifax, Nova Scotia

Correspondence: Dr ABR Thomson, University of Alberta, 519 Robert Newton Research Building, Edmonton, Alberta T6G 2C2.

Telephone 403-492-6490, fax 403-492-7964, e-mail alan.thomson@ualberta.ca

Received for publication October 21, 1994. Accepted December 6, 1995 
cevoir un traitement quotidien par 20 mg d'oméprazole ou 300 mg de ranitidine, quatre semaines durant. En tout, 1481 patients (1 001 sous oméprazole et 480 sous ranitidine) porteurs d'un diagnostic d'oesophagite de reflux $(n=904)$ et/ou d'ulcère duodénal $(n=577)$, endoscopie ou repas baryté à l'appui, et faisant état de symptômes modérés à graves ont été inclus dans les analyses. La gravité des symptômes globaux éprouvés durant le jour par le groupe sous oméprazole lors des consultations a été moins marquée que pour le groupe sous ranitidine à la semaine deux, pour le groupe entier des patients $(P=0,0002)$ et à la semaine deux et à la semaine quatre pour le sous-groupe de patients atteints d'oesophagite de reflux $(\mathrm{P}=0,0001$ et $\mathrm{P}=0,0001$, respectivement). La gravité des symptômes nocturnes globaux signalés par le groupe sous oméprazole était moins marquée que pour le groupe sous ranitidine à la semaine quatre, pour tous les patients dans l'ensemble $(\mathrm{P}=0,042)$ et à la semaine deux et à la semaine quatre pour le sousgroupe de patients atteints d'oesophagite de reflux $(\mathrm{P}=0,035$ et $\mathrm{P}=0,010$, respectivement). Aucune différence significative n'a été sig-

$\mathrm{O}^{\prime}$ meprazole, a substituted benzimidazole, acts by selective, noncompetitive inhibition of the $\mathrm{H}^{+}, \mathrm{K}^{+}$-ATPase enzyme in the parietal cell. Omeprazole $20 \mathrm{mg} /$ day or more has been shown to inhibit both basal and stimulated gastric acid secretion markedly (1).

When this study was initiated, ranitidine was considered to be the standard therapy for treatment of symptoms associated with gastroesophageal reflux disease (GERD), uncomplicated duodenal ulcers (DU) or both. Therefore, the primary objective of the study was to compare treatment with omeprazole versus ranitidine for the relief of symptoms. The number of days with pain and the occurrence of adverse events were also compared. A further objective was to identify demographic or general lifestyle factors in this mixed population of patients predictive of a positive or negative response to treatment.

This study was conceived and conducted under the direction of a Steering Committee, and was designed to be a collaborative effort between gastroenterologists and general practitioners.

\section{PATIENTS AND METHODS}

In this randomized, single-blind, parallel group study, patients were treated with either omeprazole $20 \mathrm{mg}$ daily or ranitidine $300 \mathrm{mg}$ daily for four weeks. Omeprazole was dosed once daily in the morning; ranitidine was dosed once daily in the evening in GERD patients and twice daily (in the morning and evening) in DU patients. All dosing was performed in accordance with the manufacturers' instructions, which are approved by Canadian regulatory authorities.

Eligible patients were at least 18 years old with the ability to understand the study requirements and to give informed consent. Patients reported moderate to severe symptoms at baseline. Diagnoses of GERD (at least grade I) and/or DU were verified by endoscopy or barium meal. For the purposes of this study, GERD was categorized as follows: grade I, erythema/erosions; grade II, linear ulcerations; grade III, non- nalée sur le plan des réactions indésirables. Dans le groupe sous oméprazole, $19 \%$ des patients à la semaine deux et $15 \%$ des patients à la semaine quatre ont signalé des réactions indésirables; les proportions correspondantes pour le groupe sous ranitidine ont été de $21 \%$ et de $11 \%$. En conclusion, les patients atteints d'oesophagite de reflux, d'ulcère duodénal, ou des deux, traités par oméprazole à raison de 20 mg par jour pendant quatre semaines ont manifesté des rémissions statistiquement significatives de leurs symptômes en comparaison avec les patients traités par ranitidine à raison de $300 \mathrm{mg}$ par jour pendant la même période de temps. Le pourcentage de patients présentant des symptômes diurnes était de $12 \%$ moindre dans le groupe sous oméprazole que dans le groupe sous ranitidine à la semaine deux et de 7\% inférieur à la semaine quatre. Le pourcentage de patients du groupe sous oméprazole ayant manifesté des symptômes diurnes résiduels était de 12 $\%$ inférieur à celui du groupe sous ranitidine à la semaine deux et de 7\% inférieur à la semaine quatre. Le nombre de patients du groupe sous oméprazole ayant présenté des symptômes nocturnes à la semaine deux ou quatre était de $5 \%$ inférieur.

TABLE 1

Patient diagnoses at baseline

\begin{tabular}{|c|c|c|}
\hline & \multicolumn{2}{|c|}{ Number of patients (\%) } \\
\hline & $\begin{array}{l}\text { Ranitidine } \\
\text { group }\end{array}$ & $\begin{array}{c}\text { Omeprazole } \\
\text { group }\end{array}$ \\
\hline Patients enrolled & $495(32.4)$ & $1035(67.6)$ \\
\hline \multicolumn{3}{|l|}{ Diagnosed with GERD alone } \\
\hline Ungraded (barium meal) & $26(5.3)$ & $47(4.5)$ \\
\hline Grade I & $75(15.2)$ & $167(16.1)$ \\
\hline Grade II & $100(20.2)$ & $260(25.1)$ \\
\hline Grade III & $58(11.7)$ & $123(11.9)$ \\
\hline Grade IV & $14(2.8)$ & $34(3.3)$ \\
\hline Total & $273(55.2)$ & $631(61.0)$ \\
\hline Diagnosed with DU ( \pm GERD) & $207(41.8)$ & $370(35.7)$ \\
\hline $\begin{array}{l}\text { Total included in analyses } \\
\text { (confirmed diagnoses) }\end{array}$ & $480(97.0)$ & $1001(96.7)$ \\
\hline \multicolumn{3}{|l|}{ Total excluded from analyses } \\
\hline No GERD/DU diagnosis & $10(2.0)$ & $19(1.8)$ \\
\hline Diagnostic tests not done & $5(1.0)$ & $15(1.4)$ \\
\hline
\end{tabular}

DU Duodenal ulcer; GERD Gastroesophageal reflux disease

TABLE 2

Patient characteristics at baseline

\begin{tabular}{lcc}
\hline & \multicolumn{2}{c}{ Mean \pm SD } \\
Characteristic & Ranitidine group & Omeprazole group \\
\hline Numbers & $480(275 \mathrm{M} / 205 \mathrm{~F})$ & $1001(568 \mathrm{M} / 433 \mathrm{~F})$ \\
Age (years) & $45 \pm 15.3$ & $47 \pm 14.9$ \\
Weight $(\mathrm{kg})$ & $74.0 \pm 15.6$ & $74.3 \pm 14.8$ \\
Height (cm) & $167.1 \pm 10.4$ & $167.4 \pm 10.5$ \\
Pulse (beats/min) & $75.0 \pm 7.8$ & $74.3 \pm 8.1$ \\
Systolic blood pressure & $126.8 \pm 17.8$ & $127.0 \pm 16.8$ \\
$\quad$ (mmHg) & & \\
Diastolic blood & & \\
$\quad$ pressure (mmHg) & $77.4 \pm 9.5$ & $77.6 \pm 9.4$ \\
\hline
\end{tabular}

F Female; M Male

circumferential ulcerations; and grade IV, circumferential ulcerations. The subgroup classified as 'patients with GERD' were diagnosed with GERD alone; 'patients with DU' had DU with or without associated GERD. Patients with other esophageal abnormalities, histories of gastric or pyloric ul- 
TABLE 3

Symptoms at baseline

\begin{tabular}{lcc}
\hline & Ranitidine group & $\begin{array}{c}\text { Omeprazole } \\
\text { group }\end{array}$ \\
\hline Numbers & $480(32.4)$ & $1001(67.6)$ \\
Predominant symptoms* & $177(36.9)$ & $366(36.6)$ \\
$\quad$ Epigastric pain & $137(28.5)$ & $315(31.5)$ \\
Heartburn & $53(11.0)$ & $89(8.9)$ \\
Chest pain & $39(8.1)$ & $76(7.6)$ \\
Reflux & $30(6.3)$ & $66(6.6)$ \\
Nausea or gas & $17(3.5)$ & $39(3.9)$ \\
Other abdominal pain & $14(2.9)$ & $27(2.7)$ \\
Pain/difficulty & $13(2.7)$ & $21(2.1)$ \\
swallowing & $0(0.0)$ & $2(0.2)$ \\
Other & & \\
None & & $11.4(19.0)$ \\
Average duration of & $8.8(15.2)$ & $5.3(11.6)$ \\
symptoms (months) & \\
All patients & $4.5(10.6)$ & $14.9(21.4)$ \\
DU & $12.1(17.3)$ & \\
GERD &
\end{tabular}

${ }^{*}$ Expressed as number (\%); ${ }^{\dagger}$ Expressed as mean (SD). DU Duodenal ulcer GERD Gastroesophageal reflux disease

TABLE 4

Lifestyle factors and concomitant medications

\begin{tabular}{|c|c|c|}
\hline & \multicolumn{2}{|c|}{ Number of patients (\%) } \\
\hline & Ranitidine group & $\begin{array}{c}\text { Omeprazole } \\
\text { group }\end{array}$ \\
\hline Numbers & $480(32.4)$ & $1001(67.6)$ \\
\hline \multicolumn{3}{|l|}{ Employment status } \\
\hline Unemployed & $85(17.7)$ & $188(18.8)$ \\
\hline Part-time & $39(8.1)$ & $74(7.4)$ \\
\hline Full-time & $260(54.2)$ & $553(55.2)$ \\
\hline Home-maker & $81(16.9)$ & $158(15.8)$ \\
\hline Retired & $15(3.1)$ & $28(2.8)$ \\
\hline $\begin{array}{l}\text { Tobacco use } \\
\text { (cigarettes/pipe/cigars) }\end{array}$ & $174(36.3)$ & $355(35.5)$ \\
\hline \multicolumn{3}{|l|}{ Alcohol consumption } \\
\hline None & $267(55.6)$ & $583(58.3)$ \\
\hline 1-2 drinks/week & $88(18.3)$ & $181(18.1)$ \\
\hline 3-4 drinks/week & $40(8.3)$ & $72(7.2)$ \\
\hline 5-6 drinks/week & $25(5.2)$ & $44(4.4)$ \\
\hline $7+$ drinks/week & $59(12.3)$ & $121(12.1)$ \\
\hline Missing & $1(0.2)$ & $0(0.0)$ \\
\hline \multicolumn{3}{|l|}{ Coffee consumption } \\
\hline None & $93(19.4)$ & $218(21.8)$ \\
\hline $1-2$ cups/day & $169(35.2)$ & $34(34.0)$ \\
\hline 3-4 cups/day & $122(25.4)$ & $232(23.2)$ \\
\hline 5-6 cups/day & $58(12.1)$ & $133(13.3)$ \\
\hline $7+$ cups/day & $38(7.9)$ & $77(7.7)$ \\
\hline Missing & $0(0.0)$ & $1(0.1)$ \\
\hline \multicolumn{3}{|l|}{ Concomitant medications } \\
\hline NSAIDs & $37(7.7)$ & $80(8.0)$ \\
\hline Other & $200(41.7)$ & $421(42.1)$ \\
\hline
\end{tabular}

cers, serious concomitant diseases or diseases known to affect esophageal motility were excluded from the study.

Before inclusion, a physical examination was performed and a general medical history was taken, which included de- tails on the use of alcohol, tobacco and nonsteroidal antiinflammatory drugs (NSAIDs) including acetylsalicylic acid. Each subject was assigned to omeprazole or ranitidine treatment according to a computer-generated randomization list. The randomization was blocked at each centre, so for every six subjects randomized, four received omeprazole and two received ranitidine. This 2:1 ratio favouring treatment with omeprazole increased the likelihood of observing low frequency adverse events with omeprazole (the novel treatment at the time), while still maintaining the power of the study to detect a treatment difference.

The single-blind design was maintained by sealing the two treatments in identical, opaque packages which were not opened until the patients left the clinic. Each package was labelled with a sequential randomization number and dosing instructions, and contained a one-month supply of medication.

The following daytime and night-time symptoms were assessed: pain (chest, epigastric, other abdominal, difficulty or pain in swallowing), reflux, heartburn, and nausea or gas. The seven symptoms (four pain-related symptoms and three others) were rated as follows: none, no symptoms; mild, occasional episodes easily tolerated and not interfering with normal activities; moderate, daily episodes occasionally interfering with normal activities; and severe, daily episodes constantly interfering with normal activities. Symptoms were assessed by a physician at the baseline clinic visit and after two and four weeks of treatment. Symptoms, use of concomitant medications, adverse events and complaints were recorded by the patients in a daily diary during the first two weeks of treatment.

To analyze symptom severity at clinic visits, the most severe of the seven symptoms was chosen for each patient and visit, and categorized by severity and treatment group. To analyze pain severity, the same method was employed using only the four pain-related symptoms. The number of recorded days and nights with pain in the diaries was also compared. For this analysis, days and nights were categorized according to the pain experienced - any pain (mild, moderate or severe pain), moderate or severe pain (ignoring mild pain) or severe pain (ignoring mild and moderate pain). For each patient, the number of days and nights with the various categories of pain was prorated to account for missed diary recordings. Information on adverse events was compiled from the results of open questioning at clinic visits and from patient diaries.

All data were analyzed using two-tailed $\chi^{2}$ tests. Subgroup analyses according to diagnostic category were performed in addition to analyses of the entire patient population.

The final protocol for this study was reviewed and approved by 12 institutional ethics committees located across Canada. Physicians without access to an institutional review board provided signed documentation to this effect. Patient informed consent was obtained.

Data collected on preprinted case record forms were entered via DataFax (an automated data entry system that integrates fax and computer technologies) into a database at McMaster University, Hamilton, Ontario. All data were 


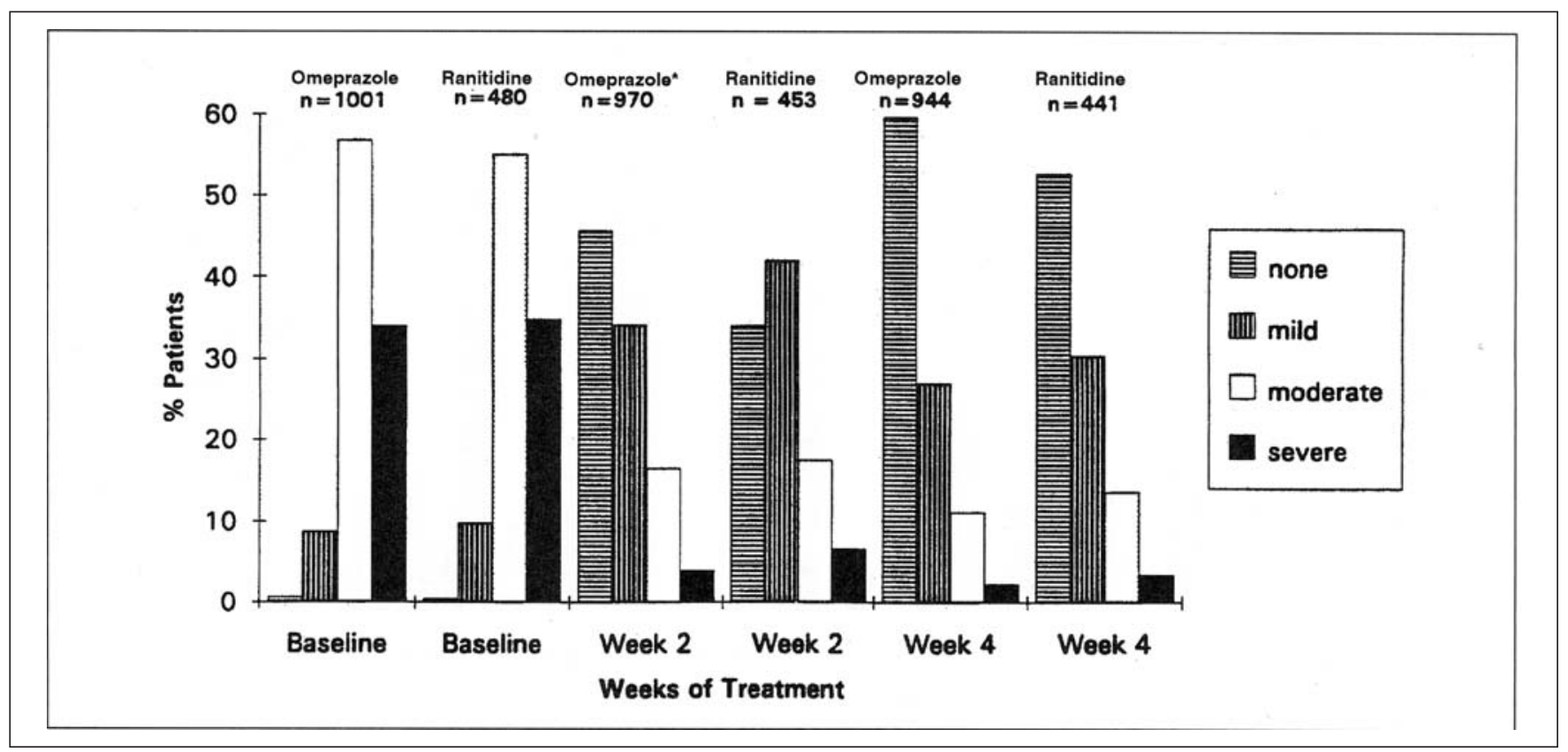

Figure 1) Percentage of all patients with differing degrees of daytime symptoms (none, mild, moderate and severe) at baseline, two weeks and four weeks of treatment with either omeprazole or ranitidine. *Severity of daytime symptoms reported by the omeprazole group was significantly lower than that reported by the ranitidine group at week 2 only $(P=0.0002)$

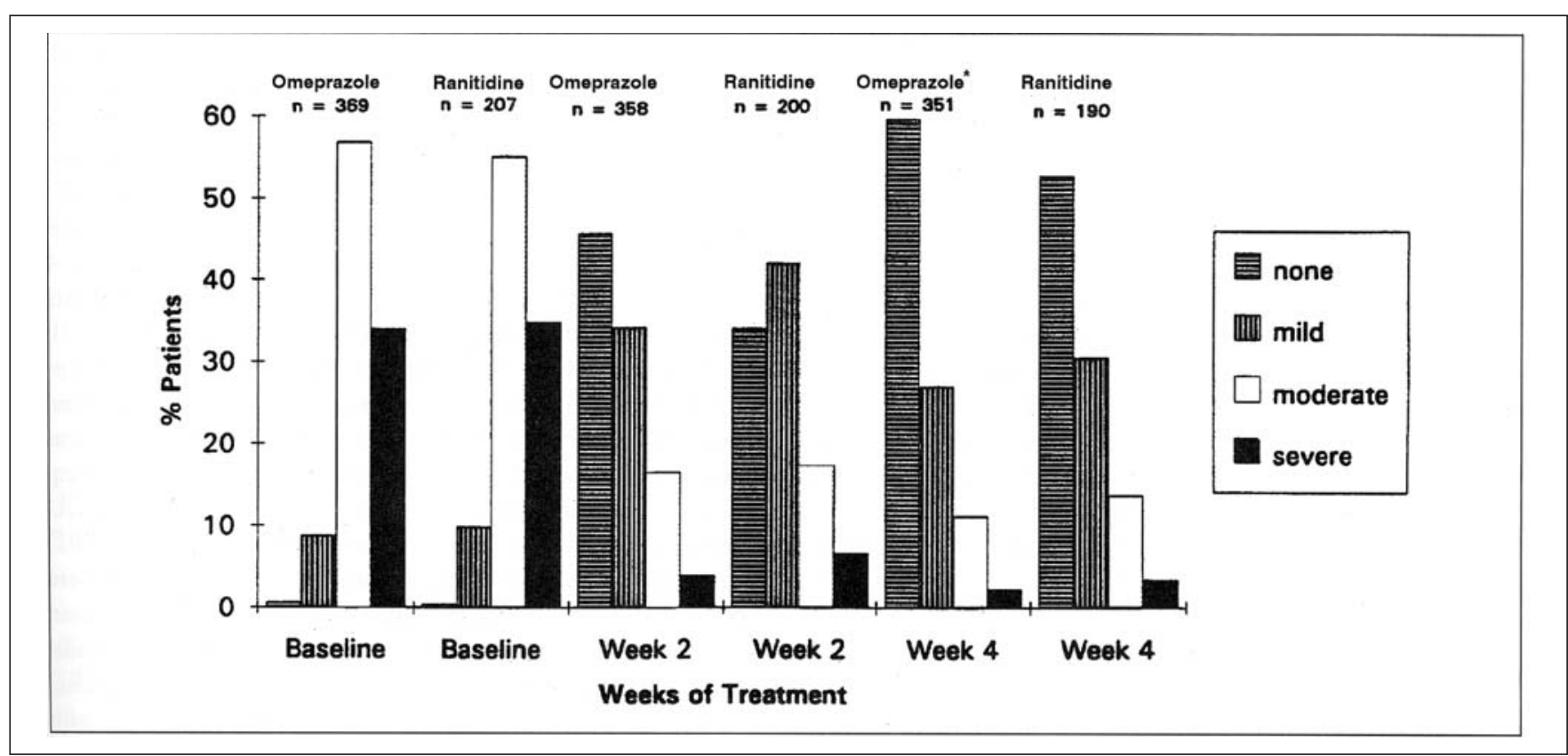

Figure 2) Percentage of all patients with differing degrees of night-time symptoms (none, mild, moderate and severe) at baseline, two weeks and four weeks of treatment with either omeprazole or ranitidine. *Severity of night-time symptoms reported by the omeprazole group was significantly lower than that reported by the ranitidine group at week 4 only $(P=0.042)$

transmitted by fax from study sites directly into a computer at McMaster University. The DataFax software running on this central computer read the fax, entered its data into the appropriate study database and stored the fax on optical disc. Staff at the coordinating centre reviewed the data via computer using a split-screen display of the fax and corresponding data entry screens. Errors or omissions were electronically flagged and faxed back to the study sites for correction/clarification.

\section{RESULTS}

In total, 1530 subjects were randomized (1035 to omeprazole, 495 to ranitidine) across Canada under the care of 111 gastroenterologists and 202 general practitioners. Forty-nine 


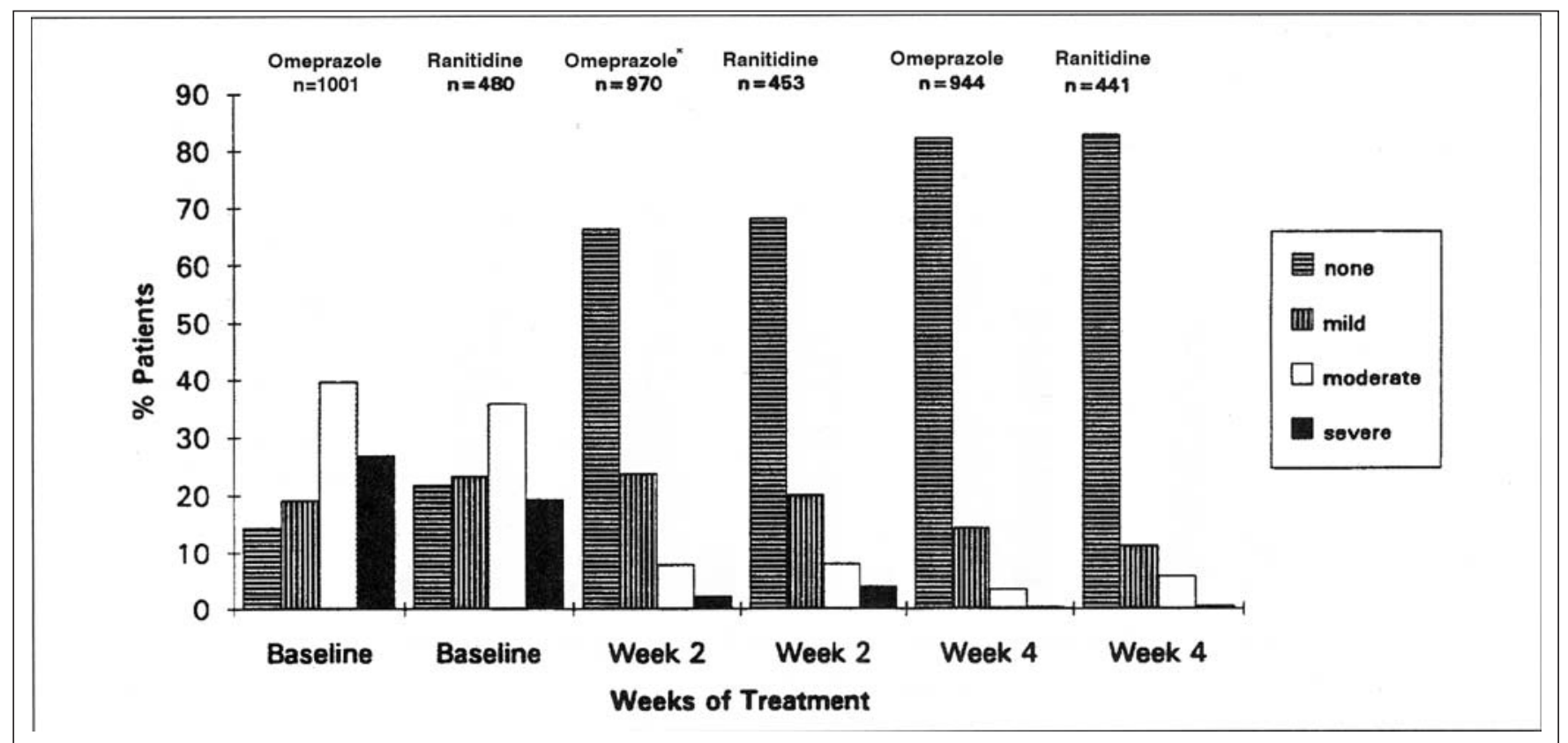

Figure 3) Percentage of all patients with differing degrees of daytime pain (none, mild, moderate and severe) at baseline, two weeks and four weeks of treatment with either omeprazole or ranitidine. *Severity of daytime pain reported by the omeprazole group was significantly lower than that reported by the ranitidine group at week 2 only $(P=0.005)$

subjects without a confirmed diagnosis of GERD or DU were excluded from the analyses. Of the remaining 1481 subjects, 904 (61\%) had a diagnosis of GERD alone and 577 (39\%) had a diagnosis of DU with or without GERD. A higher percentage of patients with DU were randomized to ranitidine treatment, while a higher percentage of patients with GERD were randomized to omeprazole. A breakdown of enrolment by diagnosis is shown in Table 1 .

All available data from the 1481 patients with confirmed diagnoses were included in all analyses, regardless of the extent of the patients' compliance with the study protocol. Patient follow-up was excellent at both of the clinic visits (weeks 2 and 4 of treatment) and for the two-week period of patient daily diary recordings. Data were available for between $92 \%$ and $97 \%$ of patients for all analyses, and were comparable across the two treatment groups and the two diagnostic categories.

The two treatment groups were well matched at baseline in terms of patient characteristics (Table 2). Table 3 presents information on baseline symptoms. Predominant symptoms were comparable between treatment groups; however, the average duration of symptoms in the omeprazole group was 2.6 months longer than in the ranitidine group, a difference that was statistically significant $(2 \mathrm{P}=0.011)$. The duration of symptoms was longer in patients with GERD in both treatment groups, suggesting that the imbalance in symptom duration between treatment groups was most probably due to the larger percentage of patients with GERD. Lifestyle factors and the use of concomitant medications at baseline are listed in Table 4.

The severity of daytime and night-time symptoms in all patients is presented in Figures 1 and 2. The severity of over- all daytime symptoms reported by the omeprazole group at clinic visits was lower than that reported by the ranitidine group for all patients at week $2(\mathrm{P}=0.0002)$ (Figure 1$)$ and for GERD patients (data not shown) at week $2(\mathrm{P}=0.0001)$ and week $4(\mathrm{P}=0.001)$. The severity of overall night-time symptoms reported by the omeprazole group at clinic visits was lower than that reported by the ranitidine group at week 4 for all patients $(\mathrm{P}=0.042)$ (Figure 2$)$ and for GERD patients (data not shown) at week $2(\mathrm{P}=0.035)$ and week $4(\mathrm{P}=0.010)$.

The severity of the subgroup of pain-related symptoms during the day and night is shown in Figures 3 and 4. Daytime pain reported by the omeprazole group at clinic visits was significantly lower than that reported by the ranitidine group at week 2 for all patients $(\mathrm{P}=0.005)$ (Figure 3 ), and for DU patients at week $2(\mathrm{P}=0.014$, data not shown) and for GERD patients at week $4(\mathrm{P}=0.010$, data not shown). There were no statistically significant differences in nighttime pain (Figure 4), although differences at week 2 approached significance in all patients $(\mathrm{P}=0.059)$ and in patients with GERD $(\mathrm{P}=0.061)$, and the omeprazole group showed less severe pain than the ranitidine group in both cases. The average number of days with 'any pain' reported in the daily diaries was 1.3 days lower in the omeprazole group (4.5 days, SD 4.7) compared with the ranitidine group (5.8 days, SD 4.9) for all patients $(\mathrm{P}<0.0001)$. The average number of days with 'any pain' was also 1.3 days lower in the omeprazole group compared with the ranitidine group for GERD patients (4.6 days, SD 4.7, versus 5.9 days, $\mathrm{SD} 4.9, \mathrm{P}=0.0002)$ and for DU patients (4.3 days, SD 4.5, versus 5.6 days, SD 4.8), $\mathrm{P}=0.002$ ). No significant differences in the diary recordings of nights with 'any pain' were found. 


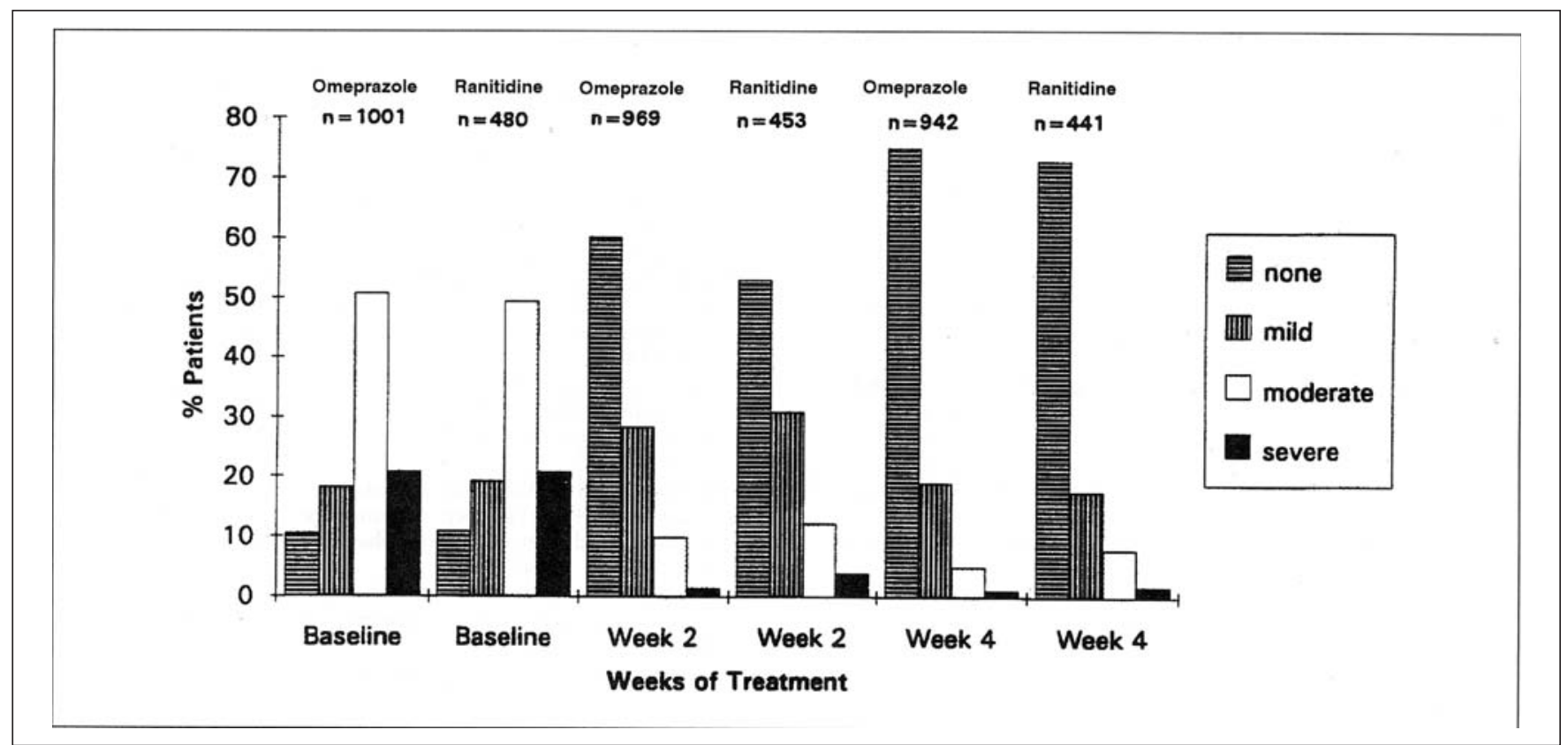

Figure 4) Percentage of all patients with differing degrees of night-time pain (none, mild, moderate and severe) at baseline, two weeks and four weeks of treatment with either omeprazole or ranitidine. There were no significant differences between treatments in night-time pain, although the difference at week 2 approached significance $(P=0.059)$, with the omeprazole group reporting less severe night-time pain than the ranitidine group

Selected analyses were repeated for the subgroup of patients who reported alcohol and/or tobacco use at baseline. The results of this subgroup analysis paralleled the results of the study as a whole. NSAID use was permitted in this study, but the number of patients using NSAIDs was insufficient to warrant a subgroup analysis.

There were no significant differences in the percentages of patients in the two treatment groups reporting adverse events at clinic visits. In the omeprazole group, 19\% of patients at week 2 and $15 \%$ of patients at week 4 reported adverse events, while the corresponding results from the ranitidine group were $21 \%$ and $11 \%$. The most commonly reported complaints in patient diaries were stomach ache, heartburn, indigestion, gas, belching and bloating - conditions commonly related to the diseases under investigation. Headache and migraine ranked next, followed by nausea and vomiting. The number of complaints registered in patient diaries was almost consistently lower in the omeprazole group compared with that in the ranitidine group; however, the differences reached significance only in week 2 for stomach ache, heartburn, indigestion $(\mathrm{P}=0.001)$ and for nausea and vomitting $(\mathrm{P}=0.007)$.

\section{DISCUSSION}

The primary objective of this study was to compare omeprazole with ranitidine for the relief of symptoms associated with GERD and/or DU. Clinic assessments and diary recordings of symptoms in this study showed that both omeprazole $20 \mathrm{mg}$ daily and ranitidine $300 \mathrm{mg}$ daily provided symptom relief at two weeks of treatment, with further improvements seen after four weeks of treatment. In all cases where statisti- cal differences in symptom relief were found (severity of daytime and night-time symptoms, severity of daytime pain and number of days without pain), the omeprazole group showed better response to treatment than the ranitidine group.

Previous studies in DU patients have demonstrated superior healing with omeprazole $20 \mathrm{mg}$ daily versus ranitidine 300 mg daily (2-5). Reduction of pain may not be a good indicator of ulcer healing (6); nevertheless, a number of studies in DU patients have shown that omeprazole also provides better symptom relief than ranitidine when used for the same time and at the same dose as those in the current study $(2,4,7)$. However, Classen et al (3) found no differences between omeprazole and ranitidine treatment with respect to symptom relief in patients with DU (3).

In patients with GERD, omeprazole in doses ranging from $20 \mathrm{mg}$ to $60 \mathrm{mg}$ daily have been shown to provide better healing than ranitidine $300 \mathrm{mg}$ daily (8-13). In studies in which symptoms were analyzed, omeprazole provided superior symptom relief compared with ranitidine at two weeks (10) and at four weeks of treatment $(8,9,11,12)$.

Modification of lifestyle factors (smoking, alcohol consumption, NSAID use) can play an important role in the treatment of acid-related disorders. In the current study, significantly better symptom relief was noticeable in the omeprazole group compared with that in the ranitidine group, even in the subgroup of patients who smoked tobacco and used alcohol (data not shown). There was an insufficient number of NSAID users to investigate the effect of this factor on healing. Further investigation into the effects of omeprazole in patients with DU and GERD using NSAIDs is warranted. 
ACKNOWLEDGEMENTS: This study was made possible by funds from Astra Pharma Inc. The DataFax data management system was developed by Wayne Taylor and Eric Bosch at McMaster University, Hamilton, Ontario.

\section{REFERENCES}

1. Clissold SP, Campoli-Richards DM, eds. Omeprazole: An Updated Review. Auckland: Adis, 1988;May:1-41.

2. Bardhan KD, Bianchi Porro G, Bose K, et al. A comparison of two different doses of omeprazole versus ranitidine in treatment of duodenal ulcers. J Clin Gastroenterol 1986;8:408-13.

3. Classen M, Dammann HG, Domschke W, et al. Kurzzeit-therapie des ulcus duodeni mit omeprazol und ranitidin. Ergebnisse einer deutschen multizenterstudie. Dtsch Med Wochenschr 1985;110:210-5.

4. Hui WM, Lam SK, Lau WY, et al. Omeprazole vs ranitidine for duodenal ulcer - one-week, low-dose regimens and factors affecting healing. Gastroenterology 1987;92:1443. (Abst)

5. Marks IN, Winter TA, Lucke W, et al. Omeprazole and ranitidine in duodenal ulcer healing. S Afr Med J 1988;24:54-6.

6. Nyrén O, Gustavsson S. Omeprazole relieves ulcer pain faster than cimetidine experience with a computerized data logger. Gastroenterology 1987;92:1556. (Abst)
7. Walan A, Bardhan KD, Bianchi Porro G, et al. A comparison of two different doses of omeprazole versus ranitidine in duodenal ulcer healing. Gastroenterology 1985;88:1625.

8. Dammann HG, Blum AL, Lux G, et al. Omeprazole is superior to ranitidine in the treatment of reflux oesophagitis. Gastroenterology 1987:90:1385. (Abst)

9. Havelund T, Laursen LS, Skoubo-Kristensen E, et al. Omeprazole and ranitidine in the treatment of reflux oesophagitis: double blind comparative trial. BMJ 1988;296:89-92.

10. Klinkenberg-Knol EC, Jansen JMBJ, Festen HPM, Meuwissen SGM, Lamers CBHW. Double-blind multicentre comparison of omeprazole and ranitidine in the treatment of reflux oesophagitis. Lancet $1987 ; \mathrm{i}: 349-51$.

11. Lundell L, Fausa O, Sandmark S. Omeprazole or ranitidine in the treatment of reflux oesophagitis - result from a double-blind, randomized Scandinavian multicentre study. Gut 1987;28:A1375. (Abst)

12. Vantrappen G, Coenegrachts JL, Rutgeerts L, Schurmans P. Omeprazole $(40 \mathrm{mg})$ is superior to ranitidine in the short term treatment of ulcerative reflux oesophagitis. Gastroenterology 1987;92:1681. (Abst)

13. Zeitoun P, Desjars de Keranroue N, Isal JP. Omeprazole versus ranitidine in erosive oesophagitis. Lancet 1987;ii:621-2. (Lett) 


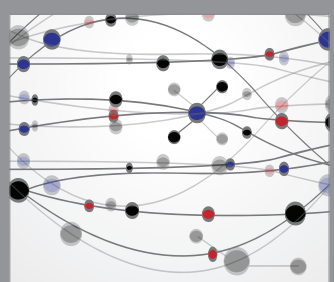

The Scientific World Journal
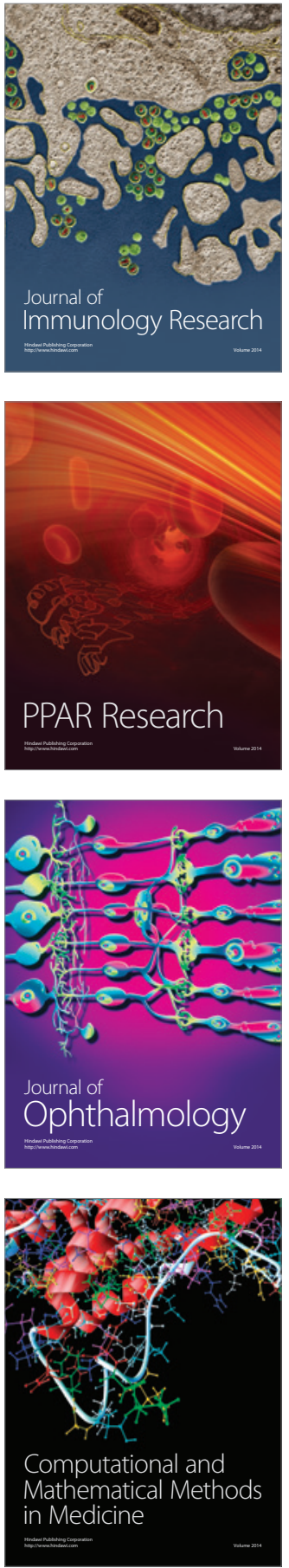

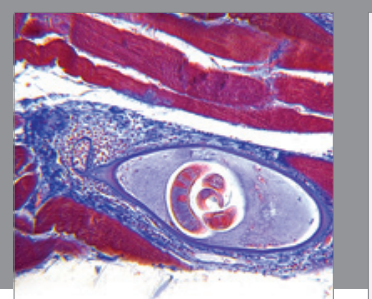

Gastroenterology Research and Practice

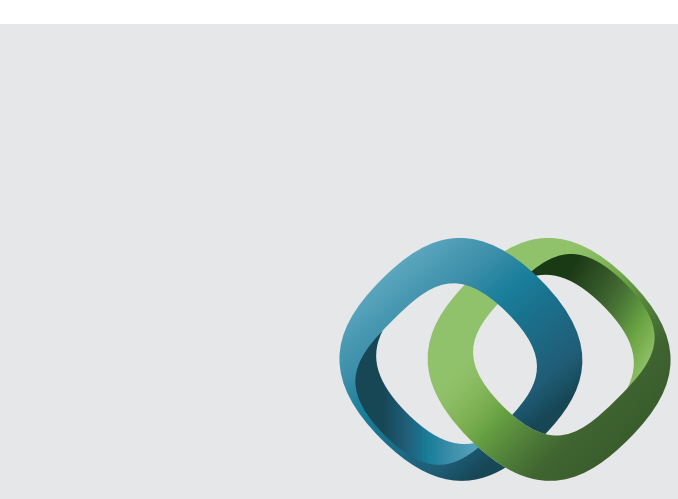

\section{Hindawi}

Submit your manuscripts at

http://www.hindawi.com
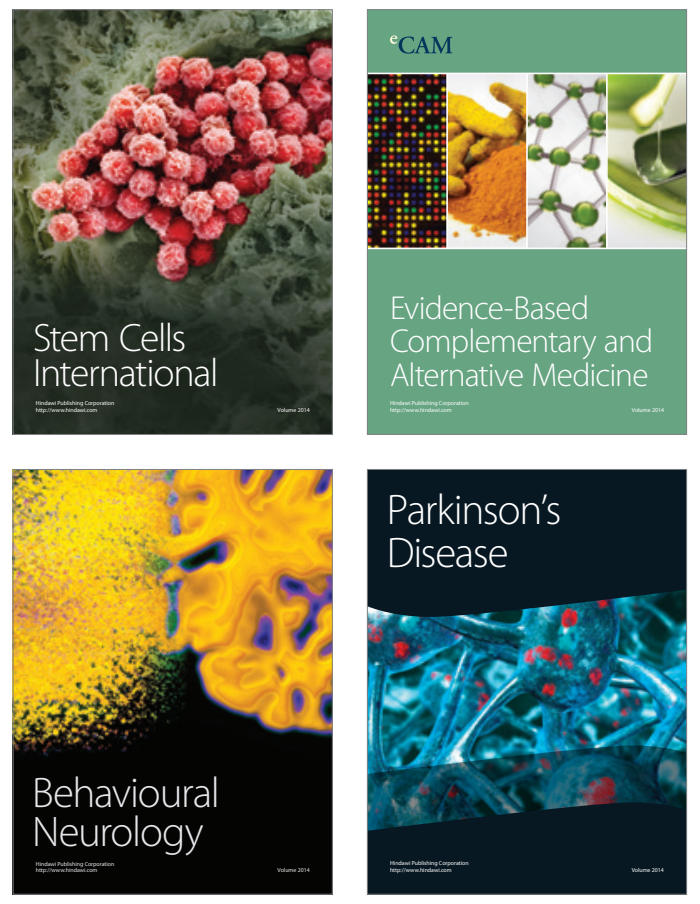
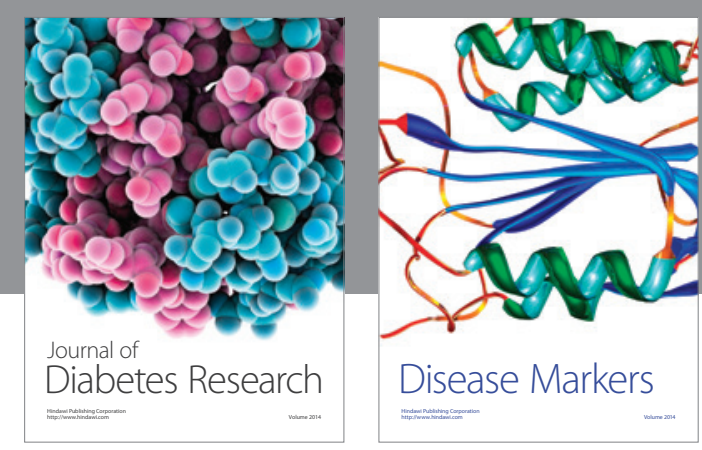

Disease Markers
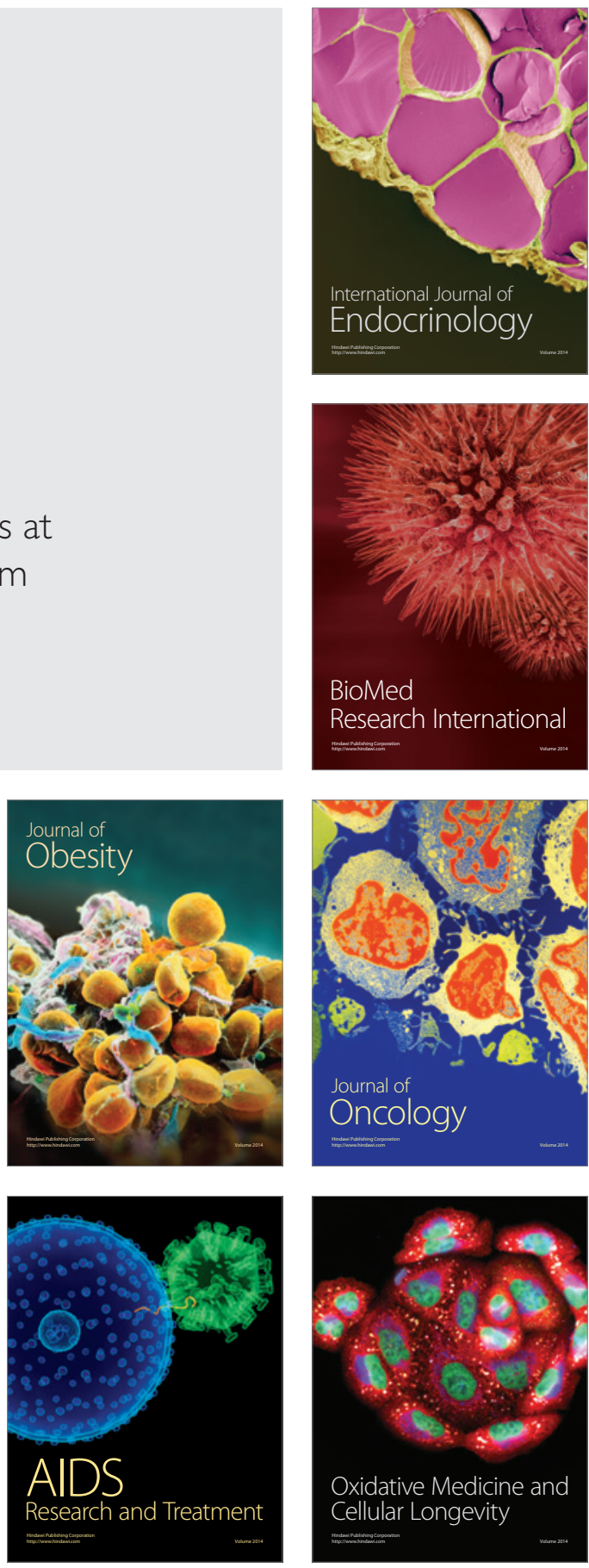